\title{
The Effect of Earnings Management to Stock Return on Company Listed in Indonesia
}

\author{
Sukiantono Tang ${ }^{1}$ and Wini Alvita ${ }^{2}$ \\ Faculty of Economy, Universitas Internasional Batam, Indonesia \\ Email: sukiantono.tang@gmail.com; 1842068@wini@uib.edu
}

\begin{tabular}{|l|}
\hline \multicolumn{1}{|c|}{ Published: 30/09/2021 } \\
\hline How to cite (in APA style): \\
Tang, S., \& Alvita, W. (2021). The Effect of Earnings Management to Stock Return on Company Listed in Indonesia. \\
Jurnal Ekonomi dan Bisnis Jagaditha, 8(2), 194-201. doi: https://doi.org/10.22225/jj.8.2.2021.194-201
\end{tabular}

\begin{abstract}
The financial report should report accurate information about the company situation so it can be utilized properly by stakeholders. This study aims to examine the effect of earnings management on stock returns. The data collection of this study used purposive sampling. A total of 1335 data were collected and used as research samples. The data that has been collected is then tested to obtain the results. Furthermore, in analyzing the data, the method used is descriptive statistics. Based on the analysis, the results of this study showed that earnings management has a significant effect on the stock return variable. This is because earnings management practices can trick investors into making investment transactions.
\end{abstract}

Keywords: Book to Market Ratio; Discretionary Accruals; Earnings Management; Stock return.

\section{INTRODUCTION}

To fulfill the requirement of capital on a company, one of the most frequently used methods is to make a stock offering. Stocks are a sign of someone's ownership of a company or business entity with a sheet of paper which's explain that the owner of the paper had a percentage of the portion from the ownership of a company or business entity (Amalya, 2018). Share purchase is one of the investment instruments. The investor who invested their money into the company hopes that they will receive a profit from their investment activities. The profit from their investment activities is called share return.

An investor can use the financial report analysis method to maximize their profit on their investment. A financial report is a report that is related to the actual condition of a company or business entity that issued the financial report. A financial report also carries information about the company or business entity's performance (Antula \& Rate, 2018). Financial report readers or stakeholders can see the performance of the business entity with a technique of comparing the business entity performance on this period with the business entity performance in the previous years. Financial report readers or stakeholders are also able to see the business entity performance by comparing it with other business entity performance which still in the same business type. Financial reports are used as an encouragement for an investor to make decisions, the financial report is also used as a source to assess the value of a company or business entity (Sucitra, Sari, \& Widyastuti, 2021).

One of the significant components contained in the financial statements is the company's profit. A company's profit usually being used by an investor to determine their investment decisions (Kurnia \& Arafat, 2015). Management can manipulate company profit by increasing or decreasing the profit in a way that is still appropriate. Earnings management is a practice conducted by company management that raised or lowered the company profit using accounting policy which is still appropriate and relevant with the accounting principle.

Several cases occur in several companies that do not convey profits in the financial 
statements with the actual one, namely PT Garuda Indonesia (Okezone, 2019). The 2018 financial report of PT Garuda Indonesia reported a net profit of USD 809,000.85 where this value increased dramatically compared to the 2017 financial report of PT Garuda Indonesia where they reported a net profit of PT Garuda Indonesia a net loss of USD 216,500,000 (Effendi, 2020). In addition, to PT Garuda Indonesia, PT Asuransi Jiwasraya also did not disclose profits in the financial statements with the actual conditions. PT Asuransi Jiwasraya reported false profits by practicing earnings management which failed insurance policy claims for PT Asuransi Jiwasraya customers (Sucitra et al., 2021). PT Kimia Farma says that the net profit at the end of the 2001 fiscal year was higher than the fact. The error in submitting the profit is because there are excess numbers in the sales and inventory accounts (Oktaviani, 2016).

One of the factors that affect stock prices is the profit reported in the financial statements. Profits reported in the financial statements will affect the investment behavior of an investor (Bhutto, Shaique, Kanwal, Matlani, \& Zahid, 2021). High profits will attract investors to invest in the company because investors judge that the company has good performance. Investors will react positively to positive news about company profits and will react negatively to negative news about company profits (Bhutto et al., 2021). Due to these factors, the management of the company is triggered to manipulate earnings to bring a favorable change in the stock price.

Several similar studies have previously examined management earnings. Nuryaman (2013) in her study examined the effect of earnings management on firm stock returns with audit quality as a moderating variable, revealed that earnings management negatively affect stock returns. The quality audit can strengthen the relationship negatively earnings management with stock return. The relationship negatively earnings management with a stock return greater for companies audited by Big 4 Audit Firm compared with Non-Big 4 Audit Firm. Audit Quality can moderate the relationship negatively earnings management with stock return. Meanwhile, Sugiyanto \& Febrianti (2021) in their study examined the effect of Green Intellectual Capital, Conservatism, and Real Earning Management on Future Stock Returns and their Implications on Stock Returns on Mining companies listed on the Indonesia Stock
Exchange Period 2014 - 2019, showed that intellectual capital has a significant effect on future stock returns, Conservatism has a significant effect on future stock returns, earning management has a significant effect on future stock returns, Implications future stock return on stock returns. These findings indicate that in sample companies, future stock returns on stock returns have no implication. In addition, a study conducted by Rachman et al. (2021) that examined the influence of real earning management toward stock returns, showed that the correlation between Real Earnings Management and Stock Return shows a very low relationship, there is a positive but insignificant relationship between stock returns based on real earnings management actions. Thus, based on the previous studies, it can be assumed that earning management can have a positive and negative effect on Stock Return on Company. Therefore, this study aims to examine the effect of earnings management on stock returns.

\section{CONCEPT AND HYPOTHESIS}

\section{Stock Return}

Investors invest their money hoping that they will receive benefits from their investments (Purba, 2019). This expected income is known as stock returns. Stock returns are the difference between the selling price of the stock and the purchase price of the stock (Bansal, Ali, \& Choudhary, 2021). The higher the selling price of shares against the purchase of shares, the higher the rate of return on shares. Returns are higher in line with the high risk as well as returns are lower in line with the low risk (Arista \& Astohar, 2012).

The value of stock returns can vary depending on variables that affect the market such as company performance, dividend distribution, the general meeting of shareholders, changes in strategy, government regulations, inflation, and interest rates set by Indonesia Bank (Oktavia \& Genjar S.N., 2018).

\section{Earnings Management Against Stock Return}

Investors need accurate financial information as a basis for them to make and determine their investment decisions (Sugiyanto \& Febrianti, 2021). Financial statements provide useful information to make investment decisions for investors (Antula \& Rate, 2018). In the process of submitting financial statements, companies can choose 
their accounting policies. This opportunity is used by the company's management to modify earnings in the financial statements. This activity is called earnings management practice. According to the results of research by Istiqomah \& Adhariani (2017), management practices applied by companies can cause negative reactions from investors which then cause the company's shares to decline. Related things occur because investors prefer to avoid the risk that will occur in companies that are proven to implement earnings management practices. This gives confidence that potential investors or investors have paid more attention to and analyzed the company's financial statements.

$\mathrm{H}_{1}$ : Earnings management has a significant effect on stock returns.

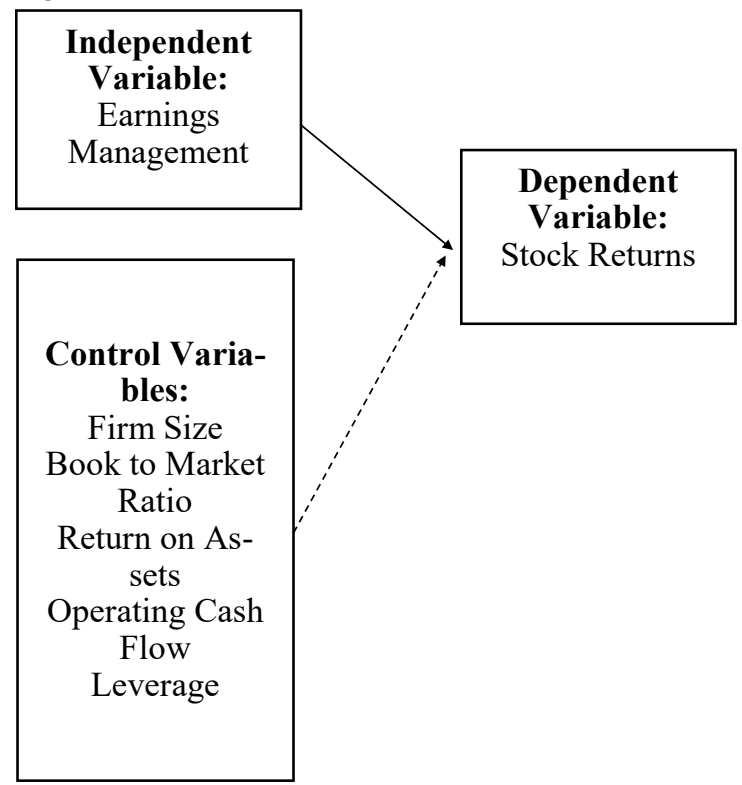

Image 1

Research Model

Source: Author, 2021

\section{METHOD}

In this study, the data used is secondary data and a purposive sampling method is used in collecting the data. Purposive sampling is a method of determining sample data based on some criteria (Sekaran \& Bougie, 2016). The data in this study were collected from financial reports issued by companies then can be accessed on the official website of the related company and the official website of the Indonesia Stock Exchange (IDX). The number of companies that meet the criteria is 277 companies with a total of 1335 data. This study uses linear regression because this study uses one dependent variable and one independent variable (Peck, Vining, \& Montgomery, 2013). The period in this research is from 2015 to 2019 . This study uses 2 types of programs to assist testing; the programs are SPSS and Eviews. SPSS is used to perform test outlier while Eviews programs are used to perform the statistic descriptive test, chow test, and panel regression test. Furthermore, in analyzing the data, the method used is descriptive statistics.

The dependent variable in this study is stock returns. The stock return variable is measured by the ratio measurement scale. An independent variable in this study is earnings management. Earnings management is a practice carried out by management to show profit results following the targets set by the company to produce positive financial reports (Baskaran, Nedunselian, Ng, Mahadi, \& Abdul Rasid, 2020). Earnings management in this study uses a model from Jones's Modified Model 1995. Jones's Modified Model 1995 is the best model used to measure discretionary accruals to detect earnings management practices in a company (Dechow, Sloan, \& Sweeney, 2015). The earnings management variable is measured using a ratio measurement scale.

The control variables in this study consisted of firm size, leverage, operating cash flow, return on assets, and book to market. Firm size is a measurement used to classify the size of a company in various ways such as total assets, sales, and market capitalization (Kurnia \& Arafat, 2015). The firm size variable uses a ratio measurement scale. Research conducted by Danso et al. (2021) measures company size by calculating the logarithm of total assets. Leverage can be used to see how big the company's assets are funded by loans from external parties (Purba, 2019). In this study, the type of leverage used is the debt to equity ratio. Leverage is measured using a ratio measurement scale. Leverage is calculated by way of dividing total debt by total assets. Operating cash flows are cash inflows and cash outflows that affect net income (Tumbel, Tinangon, \& Walandouw, 2017). Operating cash flow can be used to analyze whether the company generates sufficient cash flow to pay for operational maintenance, repay loans, make new investments, and pay dividends by not using loans from external parties or other parties (Cahyadi \& Darmawan, 2016). Operating cash flow in this study was taken from the number reported on the cash flow statement of the company's financial statements. Return on asset (ROA) is a measurement method used to determine the level of a company's ability to create income 
from its assets (Setiawan \& Sumantri, 2020). Return on asset is calculated by way of divide the net profits to total assets multiplied by $100 \%$. Book to market ratio $(\mathrm{BM})$ is the proportion of book value to market statistics on shareholder equity (Moardi, Salehi, Poursasan, \& Molavi, 2019). The book to market ratio is measured using a ratio measurement scale. Book to market to ratio is calculated by way of divide the share value of book equity into the capitalization market.

\section{RESULT AND DISCUSSION}

The results found in descriptive statistics are the value of the data tested, the minimum value, the sum of the data, the average value, standard deviation, and variance.

Table 1

Descriptive Statistics

\begin{tabular}{cccccc}
\hline & $\mathbf{N}$ & Mean & Minimum & Maximum & $\begin{array}{c}\text { Standard } \\
\text { Deviation }\end{array}$ \\
\hline SR & 1135 & 0.055168 & -0.923077 & 9.642227 & 0.590884 \\
DAC & 1135 & 0.025271 & -1.084710 & 1.222768 & 0.133798 \\
FS & 1135 & 28.85605 & 24.71236 & 32.47303 & 1.557007 \\
Leverage & 1135 & 0.554456 & 0.000242 & 28.12005 & 1.157532 \\
ROA & 1135 & 0.020960 & -10.88936 & 1.851710 & 0.339864 \\
CFO & 1135 & $5.42 \mathrm{E}+11$ & $-7.76 \mathrm{E}+12$ & $1.06 \mathrm{E}+13$ & $1.45 \mathrm{E}+12$ \\
BM & 1135 & 2.023239 & -21.56854 & 210.2898 & 9.858258 \\
\hline
\end{tabular}

Source: Data Managed by Author

Stock return variables with an average of 0.055168 , a minimum value of -0.923077 , and a maximum value of 9.642227 based on these statistical results, there is a large interval due to the different stock performance of each company which can be influenced by internal factors and external factors such as news spread in various media so that the standard deviation value reaches 0.590884 , which means that stock return on companies listed on IDX is not varied.

The DAC variable represents earnings management with an average of 0.025271 , a minimum value of -1.084710 , and a maximum value of 1.222768. Based on the results of statistic that, on average companies that do practice management profit greatly was low ie $2.5 \%$. Therefore, it can be concluded that companies listed on the IDX do not practice earnings management. A large difference between the maximum and minimum values has no significant effect on a decent standard deviation of 0.133798 , meaning that earnings management in companies listed on the IDX does not vary.

Firm size variable with an average of 28.85605 , a minimum value of 24.71236 , and a maximum value of 32.47303 . based on the results of the statistics of the companies listed on the Stock Exchange is the company scale medium company to big company. This is because to be listed on the IDX, it is necessary to meet several criteria that can not be met by a small business with an asset value of not more than 20 billion. Variable leverage with an average of 0.554456 , a minimum value of 10.88936 , and a maximum value of 28.12005 . based on these statistics, it is known that there are $55 \%$ of companies on the IDX funded by debt.

ROA variable with an average of 0.02960 , a minimum value of 1.85710 . Based on these statistical results, the average company is less able to maximize profits by using available assets. CFO variable with an average of $\mathrm{Rp}$ $542,000,000,000$, a minimum value of $-R p$ $7,760,000,000,000$ and a maximum value of $\mathrm{Rp} 10,630,000,000,000,000$. Every company of various sizes has a different operating level which will then have an impact on operating cash flow. Based on these statistical results, it can be interpreted that the average company on the IDX has a low operating cash flow.

The variable book to market ratio with an average of 2.023239, a minimum value of 21.56854 , and a maximum value of 210.2898. Based on these statistical results, the average company of the IDX performs well because investors in Indonesia are familiar with and apply fundamental analysis.

Panel data regression consists of 2 (two) kinds of data, namely cross-section and time series. The cross-section is data taken at one certain time, while time series is data taken at a certain time, for example from 2016 to 2019 (Ahmaddien \& Susanto, 2020). The linear data regression model is as follows.

$$
\mathrm{Y}_{\mathrm{i}}=\beta_{0}+\beta_{1} \mathrm{X}_{1}+\mathrm{e}_{\mathrm{i}}
$$

To estimate the model with panel data using the technique by (Singagerda, 2018), which is as follows:

Fixed Effect Model. 


\section{Random Effect Model.}

The chow test us used to choose between 2 (two) models, namely, Common Effect Model (CEM) and Fixed Effect Model (FEM). The evaluation criteria for the chow test are seen from the probability value, if the probability value is greater than 0.05 then the best model of this study is CEM, if the probability value is less than 0.05 then the best model of this study is FEM.

Tabel 2

Chow Test Results

Redundant Fixed Effects Tests

Equation: Untitled

Test cross-section fixed effects

\begin{tabular}{cccc}
\hline Effects Test & Prob & d.f. & Prob. \\
\hline $\begin{array}{c}\text { Cross-section F } \\
\begin{array}{c}\text { Cross-section Chi- } \\
\text { square }\end{array}\end{array}$ & 0.6114 & 266 & 0.6114 \\
\hline
\end{tabular}

Source: Data Managed by Author

Based on the results of the chow test above, it is known that the probability value is greater than 0.05 where the most suitable model to be used is the CEM model.

T-test or partial test is used to test whether the independent variable has a positive or negative effect on the dependent variable. The criteria for calculating the T-test are seen from the probability value, if the probability value is above 0.05 then the independent variable does not affect the dependent variable, if the probability value is below 0.05 then the independent variable affects the dependent variable.

Tabel 3

T-Test Results

\begin{tabular}{|c|c|c|c|}
\hline Variable & Prob & Conclusion & Hypothesis \\
\hline DAC & 0.0101 & Significant & Proven \\
\hline R-Squared & 0.016367 & $\begin{array}{c}\text { Mean De- } \\
\text { pendent } \\
\text { Var }\end{array}$ & 0.0551568 \\
\hline $\begin{array}{l}\text { Adjusted R- } \\
\text { Square }\end{array}$ & 0.011922 & $\begin{array}{c}\text { S.D De- } \\
\text { pendenVar }\end{array}$ & 0.590884 \\
\hline \multirow[t]{2}{*}{$\begin{array}{l}\text { S.E. of Re- } \\
\text { gression }\end{array}$} & 0.587351 & $\begin{array}{l}\text { Sum } \\
\text { Squared } \\
\text { Resid }\end{array}$ & 458.1353 \\
\hline & & $\begin{array}{l}\text { Durbin- } \\
\text { Watson } \\
\text { Stat }\end{array}$ & 2.338396 \\
\hline
\end{tabular}

\section{Source: Data Managed by Author}

In table 3 , the variable earnings management shows the value of probability below 0.05 can be interpreted that the earnings management effect exhibited significantly to the stock return due to the practice of the management carried out by the management companies tend to result in changes in the level of stock return. These results are in line with research conducted by Istiqomah \& Adhariani (2017) and Bhutto et al. (2021) which states that the practice of management earnings management do companies will cause a reaction negative of those investors who subsequently led to shares of companies that will shortly be suffering a declined by as the hypothesis on research is acceptable. Table 3 shows that the R-squared value is $1.63 \%$ while $98.37 \%$ is explained by other variables not included in the model above.

The F-test or simultaneous test is used to test whether the independent variable has a simultaneous effect on the dependent variable. To determine the effect, it can be seen from the probability value, if the probability value is above 0.05 then the independent variable has no simultaneous effect on the dependent variable, if the probability value is below 0.05 then the independent variable has a simultaneous effect on the dependent variable.

Tabel 4

F-Test Results

\begin{tabular}{cc}
\hline F-Statistic & 3.682744 \\
Prob (F-Statistic) & 0.001238 \\
\hline
\end{tabular}

\section{Source: Data Managed by Author}

Table 4 shows that the earnings management variable has a simultaneous effect on the stock return variable, which is indicated by the Prob value (F-Statistic) below 0.05 .

Multicollinearity is used to test whether in the regression model there is a correlation between independent variables (Ardian, 2019). If there is no multicollinearity, it can be concluded that the regression model is good. The criteria for the presence or absence of multicollinearity can be seen from the correlation value, if the correlation value is less than 0.8 then there is no multicollinearity between the dependent variables in the study, if the correlation value is more than 0.8 then it means that there is multicollinearity between dependent variables in the study. 
The Effect of Earnings Management to Stock Return on Company Listed in Indonesia

\begin{tabular}{ccccccc}
\hline \multicolumn{7}{c}{ Tabel 5 } \\
\multicolumn{7}{c}{ Hasil Uji Multikolinieritas } \\
\hline & DAC & FS & Leverage & ROA & CFO & BM \\
\hline DDAC & 1 & 0.048814699 & 0.198883526 & 0.388985331 & 0.301261494 & 0.05549456573 \\
& & 4818133 & 2288095 & 0347335 & 6040574 & 155038 \\
UFS & 0.04881469948 & 1 & 0.071620022 & 0.081020252 & 0.393275020 & 0.04240802552 \\
& 18133 & 1 & 95856211 & 70255622 & 3684723 & 334572 \\
LLerage & 0.19888352622 & 0.071620022 & 1 & 0.312358522 & 0.018248674 & 0.03486253814 \\
& 88095 & 95856211 & - & 9089858 & 31348061 & 15443 \\
RROA & 0.38898533103 & 0.081020252 & 0.312358522 & 1 & 0.097854636 & 0.00593918335 \\
& 47335 & 70255622 & 9089858 & & 37785475 & 4703177 \\
CCFO & 0.30126149460 & 0.393275020 & 0.018248674 & 0.097854636 & & - \\
& 40574 & 3684723 & 31348061 & 37785475 & 1 & 0.04228645289 \\
BBM & 0.05549456573 & 0.042408025 & 0.034862538 & 0.005939183 & 0.042286452 & 74339 \\
& 155038 & 52334572 & 1415443 & 354703177 & 8974339 & 1 \\
\hline
\end{tabular}

Source: Data Managed by Author

Table 5 shows that each variable does not show a value greater than 0.8 apart from the same variables. Therefore, it can be concluded that there is no multicollinearity between the independent variables in this study.

Heteroscedasticity is used to test whether in the regression model there is an inequality of variation from one observation to another (Christine et al., 2019). The criteria for assessing the existence of heteroscedasticity or not can be seen from the probability value, if the probability value is above 0.05 , it means that there is no heteroscedasticity, if the probability value is below 0.05 , it means that heteroscedasticity occurs in the regression model.

Tabel 6

Heteroscedasticity Test Results

Panel Cross-section Heteroskedasticity LR Test

Null hypothesis: Residuals are homoskedastic

Equation: Untitled

Specification: SR DAC FIRMSIZE LEVERAGE ROA CFO BM C

\begin{tabular}{cccc}
\hline \hline & Value & df & $\begin{array}{l}\text { Probabi } \\
\text { lity }\end{array}$ \\
\cline { 2 - 4 } $\begin{array}{c}\text { Likelihood } \\
\text { ratio }\end{array}$ & 3670.850 & 286 & 0.0000 \\
\hline \hline
\end{tabular}

\section{LR test summary:}

\begin{tabular}{lcc} 
& Value & df \\
\cline { 2 - 3 } Restricted & -1702.038 & 113 \\
LogL & & 113 \\
Unrestricted \\
LogL & 133.3869 & 7
\end{tabular}

Source: Data Managed by Author

Table 6 shows the probability value below 0.05 . So it can be concluded that there is heteroscedasticity in the regression model of this study.

Results of the study are supported by other studies with the same variables that Farichah (2017), Moardi et al. (2019), and Bhutto et al. (2021) in which the results of the research shows that there is a significantly relationship between earnings management with stock return. However, this research is different from the research conducted by Saedi (2018), Omush et al. (2019) dan Adiwibowo (2018) where the results of the research show that there is a significant relationship between earnings management with stock return.

Previous research conducted by Farichah (2017) showed that earnings management practices implemented by companies could cause negative reactions from investors which then caused the company's share to decline. This happens because investors prefer to avoid the risks that will occur caused by companies that are proven to implement earnings management practices. Research conducted by Bhutto et al. (2021) concluded that the value of stock returns will be low if managers are involved in earnings management practices and other manipulation activities.

\section{CONCLUSION}

Based on the results and discussion explained above, thus it can be concluded that the regression result shows a probability value of 0.001238 where this value is below 0.05 which can be interpreted that earnings management has a significant effect on the stock return variable. This is because earnings management practices can trick investors into making investment transactions. After all, investors see the potential for company development reflected in the company's profits. Investors will then find it difficult to 
know whether the company is implementing earnings management if they are not directly related or gets information from the company's internal parties. Earnings management practices that are known by investors and potential investors will have an impact on the lack of investment attractiveness in companies that implement earnings management practices which will then result in a low rate of return of shares.

\section{REFERENCE}

Adiwibowo, A. S. (2018). Pengaruh Manajemen Laba, Ukuran Perusahaan dan Leverage terhadap Return Saham dengan Kebijakan Dividen sebagai Variabel Moderasi. Jurnal Ilmiah Akuntansi Universitas Pamulang, 6 (2), 203. https://doi.org/10.32493/ jiaup.v6i2.1955

Ahmaddien, I., \& Susanto, B. (2020). Eviews-9 Analisa Regresi Data Panel. Gorontalo: Ideas Publishing.

Amalya, N. T. (2018). Pengaruh Return on Asset, Return on Equity, Net Profit Margin dan Debt to Equity Ratio Terhadap Harga Saham. Jurnal SEKURITAS (Saham, Ekonomi, Keuangan Dan Investasi), 1(3), 157-181. https://doi.org/10.32493/ skt.v1i3.1096

Antula, J. C., \& Rate, P. Van. (2018). Pengaruh Manajemen Laba dan Earnings Per Share Terhadap Return Saham pada Perusahaan Makanan dan Minuman yang Terdaftar di Bursa Efek Indonesia Periode 2012-2015. Jurnal EMBA: Jurnal Riset Ekonomi, Manajemen, Bisnis Dan Akuntansi, 5(3), 3262-3271. $\quad$ https://doi.org/https:// doi.org/10.35794/emba.v5i3.17470

Ardian, N. (2019). Pengaruh Insentif Berbasis Kinerja, Motivasi Kerja, dan Kemampuan Kerja Terhadap Prestasi Kerja Pegawai UNPAB. JEpa, 4(2), 119-132. Retrieved from https://jurnal.pancabudi.ac.id/ index.php/jepa/article/view/597

Arista, D., \& Astohar. (2012). Analisis FaktorFaktor yang Mempengaruhi Return Saham (Kasus Pada Perusahaan Manufaktur yang Go Public di BEI Periode Tahun 2005 2009). Jurnal Ilmu Manajemen Dan Akuntansi Terapan (JIMAT), 3(1), 1-15. Retrieved from http:// jurnal.stietotalwin.ac.id/index.php/jimat/ article/view/29

Bansal, M., Ali, A., \& Choudhary, B. (2021). Real Earnings Management and Stock Returns: Moderating Role of Cross-Sectional Effects. Asian Journal of Accounting Research, 6(3), 266-280. https://doi.org/10.1108/AJAR-112020-0107

Baskaran, S., Nedunselian, N., Ng, C. H., Mahadi, N., \& Abdul Rasid, S. Z. (2020). Earnings Management: A Strategic Adaptation or
Deliberate Manipulation? Journal of Financial Crime, 27(2), 369-386. https:// doi.org/10.1108/JFC-07-2019-0098

Bhutto, N. A., Shaique, M., Kanwal, S., Matlani, A., \& Zahid, H. (2021). Impact of Earnings Management Practices on Stock Return. Indonesian Capital Market Review, 13(1), 1 $-25 . \quad$ https://doi.org/10.21002/ icmr.v13i1.12839

Cahyadi, H., \& Darmawan, A. (2016). Pengaruh Economic Value Added, Market Value Added, Residual Income, Earnings dan Arus Kas Operasi terhadap Return Saham (Studi Empiris pada Perusahaan LQ-45). Media Ekonomi, 16(1), $176 . \quad$ https:// doi.org/10.30595/medek.v16i1.1144

Christine, D., Wijaya, J., Chandra, K., Pratiwi, M., Lubis, M. S., \& Nasution, I. A. (2019). Pengaruh Profitabilitas, Leverage, Total Arus Kas dan Ukuran Perusahaan terhadap Financial Distress pada Perusahaan Property dan Real Estate yang Terdapat di Bursa Efek Indonesia Tahun 2014-2017. Jesya (Jurnal Ekonomi \& Ekonomi Syariah), 2(2), 340350. https://doi.org/10.36778/jesya.v2i2.102

Danso, A., Lartey, T. A., Gyimah, D., \& AduAmeyaw, E. (2021). Leverage and Performance: Do Size and Crisis Matter? Managerial Finance, 47(5), 635-655. https://doi.org/10.1108/MF-10-2019-0522

Dechow, P. M., Sloan, R. G., \& Sweeney, A. P. (2015). Detecting Earnings Management. In Asian Financial Statement Analysis (Vol. 70, pp. 73-105). https:// doi.org/10.1002/9781119204763.ch4

Effendi, B. (2020). Manajemen Laba: Kontribusi Profitabilitas, Ukuran Perusahaan, dan Leverage Pada Perusahaan Tekstil dan Garmen yang Terdaftar di Bursa Efek Indonesia. STATERA: Jurnal Akuntansi Dan Keuangan, 2(2), 159-166. https:// doi.org/10.33510/statera.2020.2.2.159-166

Farichah, F. (2017). Management Compensation and Auditor Reputation on Earnings Management and on Share Returns. European Research Studies Journal, XX (3A), 196-208. https://doi.org/10.35808/ ersj/704

Istiqomah, A., \& Adhariani, D. (2017). Pengaruh Manajemen Laba terhadap Stock Return dengan Kualitas Audit dan Efektivitas Komite Audit sebagai Variabel Moderasi. Jurnal Akuntansi Dan Keuangan, 19(1), 112. https://doi.org/10.9744/jak.19.1.1-12

Kurnia, L., \& Arafat, M. Y. (2015). Pengaruh Manajemen Laba dan Ukuran Perusahaan Terhadap Biaya Modal Ekuitas pada Perusahaan Manufaktur yang Terdaftar di Bursa Efek Indonesia. Jurnal Ilmiah Wahana Akuntansi, 10(1), 45-70. Retrieved from http://journal.unj.ac.id/unj/index.php/ wahana-akuntansi/article/view/874

Moardi, M., Salehi, M., Poursasan, S., \& Molavi, 
H. (2019). Relationship between Earnings Management, CEO Compensation, and Stock Return on Tehran Stock Exchange. International Journal of Organization Theory \& Behavior, 23(1), 1-22. https:// doi.org/10.1108/IJOTB-12-2018-0133

Nuryaman. (2013). The Influence of Earnings Management on Stock Return and the Role of Audit Quality as a Moderating Variable. International Journal of Trade, Economics and Finance, 4(2), 73-78. https:// doi.org/10.7763/IJTEF.2013.V4.263

Okezone. (2019). Kronologi Kasus Laporan Keuangan Garuda Indonesia Hingga Kena Sanksi. Retrieved from Okezone Economy website: https://economy.okezone.com/

Oktavia, I., \& Genjar S.N., K. (2018). FaktorFaktor Yang Mempengaruhi Harga Saham Perusahaan Telekomunikasi. Seminar Nasional Manajemen Dan Bisnis Ke-3 Program Studi Manajemen Fakultas Ekonomi Dan Bisnis Universitas Jember, 414-422. Retrieved from https:// jurnal.unej.ac.id/index.php/prosiding/article/ download/9187/6152

Oktaviani, H. D. (2016). Pengaruh Ukuran Dewan Direksi, Proporsi Dewan Komisaris Independen, dan Ukuran Komite Audit Terhadap Praktik Manajemen Laba Pada Perusahaan Farmasi. Jurnal Akuntansi Akunesa, 4(2), 1-24. Retrieved from https:// jurnalmahasiswa.unesa.ac.id/index.php/ jurnal-akuntansi/article/view/14728

Omush, A. M. Al, Masadeh, W. M., \& Zahran, R. M. (2019). The Impact of Earnings Management on Stock Returns for Listed Industrial Firms on the Amman Stock Exchange. Business and Economic Research, 9(3), 1. https://doi.org/10.5296/ ber.v9i3.15011

Peck, E. A., Vining, G. G., \& Montgomery, D. (2013). Introduction to Linear Regression Analysis. In Introduction to Linear Regression Analysis (p. 679). New Jersey: John Wiley \& Sons Ltd.

Purba, N. M. B. (2019). Pengaruh Profitabilitas, Likuiditas, dan Leverage Terhadap Return Saham Perusahaan Manufaktur Di BEI. Jurnal Akuntansi Keuangan Dan Bisnis, 12 (2), 67-76. https://doi.org/https:// doi.org/10.35143/jakb.v12i2.2499

Rachman, A. A., Rachmawati, R., Sjaiful, R. L., Jayaatmaja, M. A., Dianita, M., Sukma, I., \& Barus, L. (2021). The Influence of Real Earning Management toward to Stock Returns. Turkish Journal of Computer and Mathematics Education (TURCOMAT), 12 (8), 1640-1646. https://doi.org/https:// doi.org/10.17762/turcomat.v12i8.3219

Saedi, A. A. Al. (2018). Earnings Management and Its Relationship With Stock Returns: An Empirical Study On A Sample of Qatari Listed Industrial Companies. Academy of
Accounting and Financial Studies Journal, 22(5). Retrieved from https:// www.abacademies.org/articles/earningsmanagement-and-its-relationship-with-stock -returns-an-empirical-study-on-a-sample-ofqatari-listed-industrial-companies-7495.html

Sekaran, U., \& Bougie, R. (2016). Research Methods for Business: A Skill-Building Approach. In John Wiley \& Sons Ltd. Italy: John Wiley \& Sons Ltd.

Setiawan, A., \& Sumantri, M. B. A. (2020). The Effect of Return on Asset (ROA), Debt to Equity Ratio (DER), and Earning Per Share (EPS) on Stock Prices in the Mining Sector on the Indonesia Stock Exchange for the 2015 - 2019 Period. Technium, 2(7), 324335. Retrieved from https:// techniumscience.com/index.php/technium/ article/view/2242

Singagerda, F. S. (2018). Model Regresi Panel Data dan Aplikasi Eviews. (2), 1-19. https:// doi.org/https://doi.org/10.31227/osf.io/vkx2t

Sucitra, K., Sari, R., \& Widyastuti, S. (2021). Pengaruh Manajemen Laba, Audit Tenure dan Komisaris Independen Terhadap Intergritas Laporan Keuangan. KORELASI: Konferensi Riset Nasional Ekonomi, Manajamen, Dan Akuntansi, 2(1), 713-727. Retrieved from https:// conference.upnvj.ac.id/index.php/korelasi/ article/view/1141

Sugiyanto, S., \& Febrianti, F. D. (2021). The Effect of Green Intellectual Capital, Conservatism, Earning Management, to Future Stock Return and its Implications on Stock Return. The Indonesian Accounting Review, 11(1), 93. https://doi.org/10.14414/tiar.v11i1.2286

Tumbel, G. A., Tinangon, J., \& Walandouw, S. K. (2017). Pengaruh Laba Akuntansi dan Arus Kas Operasi terhadap Return Saham pada Perusahaan Manufaktur Sektor Industri Barang Konsumsi yang Terdaftar di Bursa Efek Indonesia. Jurnal EMBA: Jurnal Riset Ekonomi, Manajemen, Bisnis Dan Akuntansi, 5(1), 173-183. Retrieved from https://ejournal.unsrat.ac.id/index.php/emba/ article/view/15539 